\title{
Dedicated REIT Mutual Fund Flows and REIT Performance
}

\author{
by \\ David Ling and Andy Naranjo* \\ *Department of Finance, Insurance, and Real Estate \\ Graduate School of Business Administration \\ Warrington College of Business \\ University of Florida \\ Gainesville, FL 32611-7168 \\ Phone: (352) 392-0153 \\ Fax: (352) 392-0301 \\ E-mail: Ling@ufl.edu; Andy.Naranjo@cba.ufl.edu
}

Initial draft: December 2003

Revised: March 2004

\begin{abstract}
This study examines the effects of weekly and monthly capital flows into the dedicated REIT mutual fund sector on aggregate REIT returns and, simultaneously, the effects of industrylevel REIT returns on subsequent REIT mutual fund flows. The dynamic relation between REIT capital flows and returns is estimated using vector autoregression (VAR) techniques. Unlike static regression techniques, our dynamic model produces estimates of the short-run relationships, long-run relationships, impulse response functions, and forecast variance decompositions. We find evidence that REIT mutual fund flows are significantly and positively related to prior returns, while prior REIT mutual fund flows do not significantly influence REIT returns. However, contemporaneous flows do appear to have an initial positive effect, which is partially reversed one period later. The positive contemporaneous effect, moreover, is the result of unexpected REIT mutual fund flows, while the expected portion is insignificant.
\end{abstract}

Our mutual fund flow data were supplied by AMD Data services. We would especially like to thank Mark Roberts, Director of Investment Research at INVESCO Real Estate, for his assistance and the Real Estate Research Institute for providing partial funding for this project. We also thank Will Goetzmann and the participants at the AREUEA meetings in San Diego, California for helpful comments and suggestions. Finally, we thank Milena Petrova for excellent research assistance. 


\section{Dedicated REIT Mutual Fund Flows and REIT Performance}

\section{Introduction}

A growing body of academic research documents a positive, contemporaneous relation between stock, bond, and mutual fund returns and capital flows into these sectors. These results reinforce the seemingly pervasive view among practitioners that capital flows, at least in part, drive returns (i.e., "price pressure" hypothesis) and that returns affect subsequent capital flows (i.e., "return chasing" hypothesis). However, an observed contemporaneous correlation between capital flows into a sector and underlying asset returns is not a sufficient condition for causality. An alternative explanation for the observed correlation is that flows and returns both respond in a similar fashion to fundamental economic variables and risk factors, such as unexpected inflation, changes in real interest rates, or revisions in expected corporate profits. If both capital flows and returns tend to increase when positive economic news is released, then a positive correlation between flows and prices does not prove the existence of capital flows price pressure, nor does it prove that investors engage in return chasing behavior.

Despite the emerging general finance literature on capital flows, asset values, and the role of investor sentiment, Ling and Naranjo (2003) were the first to investigate empirically the role of capital flows in real estate pricing dynamics. Their study examined whether total equity capital flows to the REIT industry (largely initial and secondary equity offerings) affect aggregate REIT prices and returns and, simultaneously, whether past industry-level REIT returns influence subsequent capital flows into the REIT sector. Although their conclusions are sensitive to the time period analyzed, Ling and Naranjo (2003) find that in the post-1992 time period (i.e., the “modern” REIT era) industry-level returns do not affect subsequent equity REIT capital flows, but equity flows appear to have a significant effect on REIT returns.

The Federal Reserve Board flow of funds data employed by Ling and Naranjo has both advantages and disadvantages. On the plus side, these data capture all equity capital flows into, and out of, the U.S. REIT market, not just mutual fund flows. This is clearly an advantage when attempting to detect the existence of price pressure in response to capital flows. However, the quarterly frequency of the Fed flow data has several drawbacks. First, quarterly data make it

difficult to uncover short-term price and flow effects. Second, the Fed equity flow data largely consist of initial and secondary equity offerings and the lag between the decision to issue new 
equity and the actual offering date can be substantial. This issuance lag may compromise the researcher's ability to detect patterns in the lag-lead relation between equity flows and returns. In particular, it may make it difficult to assess the effect of changes in investor sentiment on asset returns.

This paper examines the interrelationships and short- and long-run dynamics between capital flows to dedicated REIT mutual funds and industry-level REIT returns. Simultaneously, we examine whether past industry-level REIT returns influence capital flows into the REIT mutual fund sector. Net capital flows to dedicated REIT mutual funds are available (since 1991) on both a weekly and monthly basis. These higher frequency data allow for greater precision in determining the contemporaneous versus non-contemporaneous components of covariance between flows and returns.

The main tool of analysis we employ is a vector autoregression (VAR) model in which both mutual fund flows and aggregate REIT returns are specified as endogenous variables in a two equation system. We also include exogenous risk factors and variables in an attempt to purge the fund flows and returns equations of the relationship that may exist because of their mutual relation to sector specific and macroeconomic risk factors. In addition to quantifying the relation between capital flows and returns, the VAR model allows us to estimate impulse response functions for the variables of interest. These impulse response functions provide the time path of the short-run dynamic relationships that result from a shock to the variables in the system, while the forecast variance decompositions provide the forecast error variance explained by variations in the variables.

Our primary results can be summarized as follows. First, using both monthly and weekly data, we find no evidence of a relation between current REIT mutual fund flows and aggregate REIT returns in subsequent months. However, we do find a consistent and statistically significant association between current returns and subsequent fund flows, suggesting that REIT mutual fund investors may engage in return chasing behavior. As robustness checks, we also estimate models in which we decompose fund flows into anticipated and unanticipated components as well as structural VARs (i.e., restricted VARs) and VEC models. Using the restricted VAR models, we find that contemporaneous flows do appear to have an initial positive effect on returns, which is partially reversed one period later. The positive contemporaneous 
effect, moreover, is the result of unexpected REIT mutual fund flows, while the expected portion is insignificant. The VEC model estimates are qualitatively very similar to the VAR model estimates.

The study proceeds as follows. In the next section we discuss the extant literature on mutual fund flows and returns. We then describe our data sources and provide a discussion of the descriptive statistics. The following section contains an analysis of dedicated REIT mutual fund flows since 1991, including the univariate evidence on the comovement between REIT mutual fund flows and aggregate REIT returns. We then describe the VAR methodology we employ to examine the conditional covariation of fund flows and returns. In the next section we present the unrestricted VAR results using three specifications: a bivariate model, a four-factor model, and a seven-factor model. We then provide some additional robustness checks using alternative flow measures and a restricted VAR model. Our conclusions are presented in the final section.

\section{Related Literature}

Under the Efficient Market Hypothesis, asset values are not affected by capital flows or trading activity; the current market value of an asset is simply the present value of the expected future cash flows. The Efficient Market Hypothesis is predicated upon two important assumptions: investor rationality and costless arbitrage. However, in recent years, a burgeoning behavioral finance literature has called into question both of these assumptions. There now exists an interesting class of theoretical models that assume limited arbitrage and/or heterogeneous investor beliefs or, more specifically, the existence of "noise traders." In these models, mechanisms exists by which investor sentiment, capital flows, and trading volume can affect asset prices—independent of market fundamentals. ${ }^{1}$

Mutual fund flows are a widely followed barometer of investor sentiment. For example, AMG Data Services, the provider of our mutual fund flow data, state on their website that "investor sentiment shifts subtly and over time... when market inefficiencies arise as result, marginal (mutual fund) flows increase to reflect the intensity of the sentiment."2 Motivated by such practitioner claims and a lack rigorous research to support them, academics have recently

\footnotetext{
${ }^{1}$ See Clayton (2003) for a discussion of the literature that supports the notion that supply and demand can affect individual stock prices (i.e., the price pressure hypothesis).

${ }^{2}$ AMG Data Services, www.amgdata.com/scripts.
} 
begun to examine the dynamics between mutual fund flows and aggregate stock prices and returns. In the remainder of this section we briefly review this empirical literature.

Warther (1995) was one of the first to investigate the correlation of aggregate security returns and cash flows into mutual funds. In particular, his study examined whether aggregate fund flows are associated with concurrent and/or subsequent market-wide price movements. He also examined whether fund investors behave as feedback traders, moving money into and out of mutual funds in response to market-wide price movements. Using monthly, data, Warther divides fund flows into their anticipated and unanticipated components and finds that aggregate returns are correlated with concurrent unexpected fund flows. However, returns are not correlated with contemporaneous expected flows, suggesting that information about future flows contained in current flows cannot be used to predict future stock returns.

Using a two-equation simultaneous system with unexpected fund flows and aggregate stock returns as endogenous variables, as well as numerous exogenous control variables, Edwards and Zhang (1998) also find no evidence that mutual fund flows affect subsequent returns. Consistent with previous studies, Cha and Lee (2001) also fail to uncover empirical support for the hypothesis that fund flows directly affect aggregate stock prices. In summary, the existing body of research is not supportive of the hypothesis that mutual fund flows, measured on a monthly basis, drive subsequent returns. A notable exception is Fortune (1998) who, using a VAR framework similar to ours, finds some evidence of causation from fund flows to security returns.

The second, and related, hypothesis of interest is whether asset returns affect subsequent mutual fund flows. Warther $(1995,1998)$ and Remolona et al. (1997) find no relation between mutual fund returns and subsequent flows. In contrast, Edwards and Zhang (1998), Fortune (1998), Cha and Lee (2001), Karceski (2003), and Edelen and Warner (2001) conclude that aggregate mutual fund returns do affect subsequent fund flows into the sector.

Although the available empirical evidence strongly suggests that monthly fund flows do not affect industry-level returns in subsequent months, Edelen and Warner (2001) and Goetzman and Massa (2003) argue that the price pressure hypothesis cannot be rejected with monthly fund flow data because it may not reveal the true dynamic relation between fund flows and returns. Moreover, given that some evidence of return chasing behavior can be detected with monthly 
data, it may be that at higher frequencies mutual fund investors are vigorous feedback traders. This alternative hypothesis is supported by Goetzmann and Massa (2003) who, using daily data, find some evidence that fund flows decrease in response to downward market movements. They find no evidence, however, that flows respond positively to increased market pricing. Finally, Goetzman, Massa, and Rouwenhorst (2000) examine the determinants of variations in daily flows to U.S. mutual funds in 1998 and 1999. They find that adding a funds flow variable to realized return equations significantly increases explanatory power. The authors conclude that their results suggest a significant role for investor sentiment in explaining the cross-section of stock returns.

The next section describes our data and provides descriptive statistics. The findings of Edelen and Warner (2001), Goetzmann and Massa (2003), and Goetzman, Massa and Rouwenhorst (2000) motivate our use of weekly, in addition to monthly, fund flow data in our analysis of REIT fund flows and return dynamics.

\section{Data and Descriptive Statistics}

\section{Data Descriptions and Sources}

AMG Data Services collects the value of total net assets for more than 16,000 mutual fund share classes each Thursday as of Wednesday's market close. In December 2003, these assets were collectively valued at more than $\$ 6$ trillion. The weekly change in total net asset value for each fund is calculated from Thursday to Wednesday. The incremental capital inflow or outflow is equal to the change in the fund's total net asset value minus the portion of this change due to the market performance of the fund's assets. Reinvested dividends and capital gain distributions are excluded. Thus, reported flows indicate current allocation decisions exclusive of automatic investment of distributions. Flow data are available from AMG at the fund level. However, we employ aggregate data for the dedicated REIT mutual fund sector, which are available back to the first week of 1992 .

Most mutual fund data providers report to AMG on a weekly basis. However, three fund groups (in late 2003) report fund flows for a given month in the first week of the following month. These fund groups (Fidelity, Vanguard, and American Funds) controlled approximately 20 percent of dedicated REIT mutual fund assets at year end 2003. AMG includes the data for 
"monthly" fund groups in the week in which each fund group releases its information, which could lag the actual date of the flows by as much as five weeks. To prevent the lagged and lumpy data of monthly reporters from contaminating our weekly fund flows series, we exclude data from monthly reporters. However, our monthly fund flow data include the monthly reporters and are calculated by aggregating the weekly flows of weekly reporters for a particular month, plus the flows to monthly fund groups reported the following month. ${ }^{3}$

Since we investigate the dynamic behavior of REIT mutual fund flows and returns, it is important to consider the appropriate measure of fund flows in our regressions. Froot, O'Connell and Seasholes (2001) and Ling and Naranjo (2003) argue that the impact of capital flows on returns is conditional on the size of the market. Based on this argument, Ling and Naranjo create an additional flow variable for use in their regressions that is defined as total REIT equity flows in period $t$ relative to the total market capitalization of the REIT industry at the end of period $t-1$. However, scaling capital flows by the actual beginning-of-period stock market capitalization may introduce a direct effect of flows on stock price changes. This is because increases in the REIT industry's stock market capitalization reduce the ratio of flows to market capitalization-holding the dollar level of flows constant. This direct effect of price changes on relative flows would bias downward the estimated effect of lagged price changes on current flows because relative flows will appear smaller when the stock market does well (Engen and Lehnert, 2000). To avoid this potential bias, we create a relative measure of fund flows by dividing current flows by the stock market capitalization of the REITs in the NAREIT universe at the end of month or week $t$ - 3 .

Because REITs are income-oriented (i.e., "value") stocks, the dividend yield is frequently mentioned in professional publications as an important determinant of investor demand for REIT stocks. ${ }^{4}$ The use of the dividend yield in our analysis is also motivated by the work of Bekaert and Harvey (2002), who argue that in a rational pricing model, dividend yields will be decreasing in the growth rate of dividends and increasing in the discount rate. Therefore, dividend yields may be useful in capturing permanent price effects induced by a change in a sector's cost of capital. To examine the explanatory power of dividend yields, we include the National

\footnotetext{
${ }^{3}$ According to AMG, to ensure accuracy verification procedures, they identify anomalous price, asset, and flow change information. They verify their data directly from 500 information sources. A change in assets not due to fund flows or market performance reflects the addition or deletion of funds.

${ }^{4}$ See, for example, Barry Vinocur, “Taking Stock,” Realty Stock Review, November 22, 2002, p. 9.
} 
Association of Real Estate Investment Trust's (NAREIT) yield spread (YLDSP) in our analysis. YLDSP is defined as the composite NAREIT dividend yield minus the contemporaneous yield on 10-year Treasury securities. Because the general literature on capital flows suggests that, in addition to past returns, macroeconomic variables such as interest rates may affect flows, we include the one-month and one-week Treasury bill rate $\left(R_{f}\right)$ from the Center for Research in Securities Pricing (CRSP) and Board of Governor's H15 databases in our respective analyses of monthly and weekly fund flows.

To more broadly control for other potential sources of risk, we also include the FamaFrench risk factors $\left(R_{M K T}, S M B\right.$, and $\left.H M L\right)$ in selected specifications of our analysis. $R_{M K T}$ is the return on the value-weighted market portfolio, as measured by CRSP. SMB is the return on a diversified portfolio of small cap stocks in excess of the return on a portfolio of large cap stocks. $H M L$ is the return on stocks with high ratios of book to market value in excess of the returns on a portfolio of stocks with low book-to-market ratios. Although SMB and $H M L$ are not obvious candidates for inclusion as risk factors, they have consistently been found to be useful in explaining stock returns. ${ }^{5}$ Because the REIT sector is dominated by small cap stocks, increases in $S M B$ may be associated with higher REIT returns, all else equal. For several reasons, including the requirement that REITs distribute 90 percent of their taxable income as dividends, REIT stocks are also aptly characterized as "value" stocks with high book-to-market-value ratios. Thus, we posit a positive relation between $H M L$ and industry-level REIT returns; that is, as stock investors rotate out of "growth" stocks (with low book-to-market-value ratios) into value stocks, we expect the REIT sector to benefit from this rotation. ${ }^{6}$

As an alternative to total returns in our flows-returns regressions, we also employ estimates in our monthly analysis of the REIT industry's share price premium relative to the

\footnotetext{
${ }^{5}$ Fama and French (1996) show that the cross-sectional variation in expected returns associated with most equity characteristics can be explained within their three factor model. They argue that SMB and HML are state variables in an intertemporal asset pricing model, though rational asset pricing theories do not clearly show how SMB and HML are related to the underlying undiversifiable macroeconomic risks. However, there is some recent empirical and theoretical work by Liew and Vassalou (2000) and Lettau and Ludvigson (2001) that links the Fama-French factors to undiversifiable macroeconomic risks. More specifically, Liew and Vassalou (2000) show that SMB and HML are correlated with future economic growth, while Lettau and Ludvigson (2001) document the sensitivity of HML to bad news at times of economic distress.

${ }^{6}$ For a convincing demonstration that REIT stocks have behaved in recent years as small cap, value stocks, see Falzon (2002).
} 
industry's net asset value (NAV). ${ }^{7} \mathrm{NAV}$ is a per share measure of the market value of a REIT's underlying assets. More specifically, NAV is equal to the estimated market value of a REIT's properties, including the value of any development projects, plus the value of non real estate assets, minus the value of the REIT's debt obligations. This estimated net asset value is divided by the number of outstanding shares to obtain each REIT's NAV per share. A REIT's share price premium is equal to its current price divided by the estimated NAV per share. ${ }^{8}$ The industry's share price premium $(P N A V)$ is a weighted average of each firm's price premium.

What are the investment implications of the observed NAV share price premiums? If a firm's share price exceeds its estimated NAV per share, the stock market apparently perceives positive growth opportunities for the REIT that justify a share price in excess of the aggregate market value of the REIT's underlying properties. Conversely, if the share price premium is negative, this may signal that the market perceives negative growth opportunities for the firm. According to industry analysts, if a REIT's share price premium is "too high," this signals an eventual decline in the firm's stock price. Interestingly, for the industry as a whole, NAV share price premiums have displayed significant mean reversion (towards zero), which is why many in the industry feel that NAV share price premiums are predictive of future capital flows and share prices.

We obtain monthly value-weighted REIT returns $\left(R_{R E I T}\right)$ for all REITs in the NAREIT universe and dividend yield spreads (YLDSP) from NAREIT. Daily value-weighted total portfolio returns for the firms in NAREIT's changing universe of publicly traded REITs were constructed from CRSP and Compustat data. These daily returns are compounded into weekly total returns that correspond to the Thursday-Wednesday weeks used by AMG to report fund flows. Monthly U.S. T-bill yields are obtained from the CRSP database, while weekly T-bill yields were abstracted from the Federal Reserve Board's H15 database. Ken French supplied both monthly and daily Fama-French risk factors. The REIT industry's monthly share price

\footnotetext{
${ }^{7}$ Weekly NAV estimates are not available.

${ }^{8}$ The market value of the firm's in-place and development properties is estimated using direct capitalization. More specifically, the aggregate net operating income of the REIT's properties, estimated from financial statements, is divided by a weighted average capitalization rate that reflects the geographic location and property type composition of the REIT's portfolio.
} 
premiums relative to industry NAV estimates $(P N A V)$ were obtained from the website of Green Street Advisors, Inc. ${ }^{9}$

\section{Descriptive Statistics}

Univariate descriptive statistics for the variables used in our regression analyses are presented in Table 1. The mean and standard deviation of the monthly data are presented in the first two columns followed by the corresponding statistics for the weekly data. The sample period, January 1992 through August 2003, is dictated by the availability of the AMG data.

Flows to dedicated REIT mutual funds (FLOWS) averaged $\$ 86.2$ million per month and $\$ 17.2$ million per week over the study period. The standard deviation of these fund flows were \$227.5 million and \$52.6 million, respectively. Relative fund flows (RFLOWS) have averaged 0.12 percent per month since 1992 . The corresponding weekly percentage is 0.02 percent.

Monthly composite NAREIT returns, $R_{R E I T}$, have averaged 0.98 percent over the sample period with a standard deviation of 3.4 percent. Weekly returns have averaged 0.25 percent with a standard deviation of 1.80 percent. According to Green Street Advisors, the RREIT industry's average share price premium relative to NAV (PNAV) has averaged 3.52 percent per month, indicating that REITs, on average, have sold for a small premium relative to estimated NAV. The PNAV standard deviation of 10.79 percent, however, indicates a great deal of variation in this share price premium. The annualized NAREIT yield spread (YLDSP) averaged 1.21 percentage points (121 basis points) and 1.50 percentage points in the monthly and weekly data, respectively. The stock market risk premium $\left(R_{M K T}-R_{f}\right)$ has averaged 0.56 percent per month, or 6.72 percent per year, and has displayed significant volatility.

Table 2 contains the monthly and weekly contemporaneous correlations among the variables used in our regression analysis. The first column in Panels A and B reveals that raw REIT mutual fund flows (FLOWS) are highly correlated with our constructed measure of relative fund flows (monthly $\rho=0.84$, weekly $\rho=0.83$ ). Raw flows are also highly correlated with contemporaneous REIT returns. Contrary to expectations, flows are negatively correlated with REIT yield spreads ( $\rho=-0.26$ for both the monthly and weekly data). There is also a negative association between flows and yields on short-term Treasury securities $\left(R_{f}\right)$. Monthly flows are positively correlated with $H M L(\rho=0.23)$; however, the correlation is much weaker in the weekly

\footnotetext{
${ }^{9}$ see www.greenstreetadvisors.com.
} 
data $(\rho=0.09)$. The contemporaneous correlation of flows with $S M B$ is not statistically significant in either the monthly or weekly data. Finally, fund flows and industry NAV premiums display significant positive correlation. The correlations between relative flows (RFLOWS) and our regression variables (column 2 in both panels) are largely indistinguishable from the raw fund flow correlations.

Column 3 in Panels $\mathrm{A}$ and $\mathrm{B}$ reveals that industry-level REIT returns $\left(R_{R E I T}\right)$ are positively correlated with the contemporaneous market risk premium. However, the monthly correlation $(\rho=0.33)$ is weaker than the weekly relationship $(\rho=0.55) . R_{R E I T}$ displays little correlation with $Y L D S P$ and $R_{f}$. As discussed above, prior empirical studies suggest that REIT returns should be positively correlated with the contemporaneous premiums earned by small cap stocks and value stocks. The monthly correlations of $R_{R E I T}$ with $S M B(\rho=0.25)$ and $H M L(\rho=0.21)$ seem to confirm this expectation; however, the weekly correlations of $R_{R E I T}$ with $S M B$ ( $\rho=0.07$ ) and HML $(\rho=-0.08)$ do not. In contrast to REIT returns, monthly NAV premiums display no correlation with $S M B$ or $H M L$.

\section{The Behavior of REIT Mutual Fund Flows over Time}

The 1990s witnessed tremendous growth in the mutual fund industry. More than 8,000 U.S. mutual funds now hold combined assets worth more than $\$ 6.4$ trillion. ${ }^{10}$ Shares in these funds represent a major component of household wealth. The 1990s also witnessed the birth of the modern REIT era. Figure 1 displays monthly REIT mutual fund flows since 1991 (measured on the left vertical axis), as well as the percentage of the REIT industry's stock market capitalization held by dedicated REIT mutual funds (measured on the right vertical axis). Although Congress created the REIT industry in 1960, the total stock market capitalization of the REIT industry was only $\$ 13.0$ billion by year-end 1991 .

As is discussed by Ling and Ryngaert (1997), Capozza and Seguin (2003), and others, the creation of the UPREIT (umbrella partnership REIT) structure in November of 1991, along with several other regulatory and economic factors, precipitated a boom in REIT initial public offerings. By year-end 1995, the stock market capitalization of the REIT industry had increased to $\$ 57.4$ billion. Nevertheless, dedicated REIT mutual funds were slow to organize and only a

\footnotetext{
${ }^{10}$ See www.ici.org.
} 
total of \$1.6 billion in incremental investment capital flowed into REIT mutual funds from 1992 through 1995. By year end 1995, REIT mutual funds controlled a total of $\$ 2.1$ billion in assets, which represented just 3.6 percent of the REIT industry's total market capitalization.

In 1996, the NAREIT composite index produced a total return of 36 percentoutperforming both large and small cap stocks. This was followed by a total return of 19 percent in 1997. Flows to dedicated REIT funds accelerated rapidly in 1996 and 1997. By year-end 1997, REIT mutual funds controlled $\$ 11.9$ billion in assets, which represented over 8 percent of the REIT industry's market capitalization. Flows into REIT mutual funds slowed during the first half of 1998 and then turned negative in late 1998, where they largely remained during 1999. These negative fund flows were concomitant with total returns on the NAREIT index of -19 percent in 1998 and -6 percent in 1999. Although the stock market performance of REITs improved significantly in 2000, net mutual fund inflows were negligible. Since year-end 2000, monthly mutual fund flows have been largely positive, pushing the percentage of the industry's market cap held by mutual funds above 10 percent. Despite the positive trend, however, REIT mutual fund flows have been noticeably volatile.

In Figure 2, we plot NAREIT total returns and RFLOWS. Relative flows are measured on the left vertical axis, returns on the right. Figure 2 suggests a strong positive relation between mutual fund flows and aggregate NAREIT returns. Using our monthly data, we observe (column 2, Table 3) a positive contemporaneous correlation of 0.45 between monthly REIT returns and relative fund flows. The corresponding correlation for the weekly data is 0.29 . The data also reveal that REIT returns are positively correlated with fund flows in the subsequent month $(\rho=0.39)$ and week $(\rho=0.30)$. Conversely, we observe no correlation between $R_{R E I T}$ and subsequent RFLOWS. These univariate statistics suggest that returns drive flows but that flows do not drive returns.

NAV share price premiums and relative monthly fund flows, displayed in Figure 3, appear to be highly correlated and, in fact, the contemporaneous correlation is 0.60 . We also observe a strong positive correlation of 0.49 between PNAV and $R F L O W S_{t+1}$. The correlation between PNAV and RFLOWS $S_{t-1}$ is 0.59 . These univariate statistics suggest that monthly fund flows respond to prior month NAV premiums and that NAV premiums are associated with fund flows in the prior month. This latter positive correlation, however, likely results from the 
significant amount of autocorrelation $(\rho=0.93)$ in $P N A V$. We control for this autocorrelation in our regression analysis by the use of lagged $P N A V \mathrm{~s}$.

Although Figures 2 and 3 and the lag-lead correlation results in Table 3 suggest a relation between REIT returns (and NAV premiums) and mutual fund flows, they do not imply causation in any meaningful sense. To get a preliminary sense of the relation between aggregate REIT returns and mutual fund flows, we performed Granger Causality tests. ${ }^{11}$ The null that monthly REIT returns do not Granger cause subsequent monthly fund flows is rejected at the 5\% significance level, while we cannot reject the null that monthly flows do not Granger cause REIT returns. The same results are obtained with weekly data.

\section{Dedicated Mutual Fund Flows Versus Total REIT Capital Flows}

Ling and Naranjo (2003) examine the interrelationships and short- and long-run dynamics among aggregate REIT returns and total equity capital flows into the REIT sector. They argue that the use of total equity capital flows provides a potential advantage when attempting to discern whether capital flows affect returns and visa versa. Before moving on to our analysis of mutual fund flows and REIT returns, we first compare our REIT mutual fund flow data to total equity REIT capital flows. Our source of REIT equity capital flow data is the Federal Reserve Board's quarterly Z.1 statistical release "Flow of Funds Accounts of the United States." From this source we obtain the net equity issuance of public REITs, defined as the difference between gross equity issuance (a positive source of REIT funds) and equity retirements (a negative source of funds). ${ }^{12}$ These quarterly flows are displayed in Figure 4 along with our mutual fund flows.

The correlation between REIT mutual fund flows and total equity capital flows into the REIT sector is evident in Figure 4. The contemporaneous correlation between the two quarterly data series is 0.38 . Of special interest, however, is the lead-lag relationship between the two capital flow series. The correlations between REIT mutual fund flows in period $t$ and all REIT equity flows in period $t+1$ and period $t+2$ are 0.53 and 0.60 , respectively. However, the correlations between fund flows in period $t$ and all equity flows in period $t-1$ and period $t-2$, are

\footnotetext{
${ }^{11}$ It is important to note that Granger Causality measures precedence and information content, but does not by itself indicate causality in the more common use of the term.

${ }^{12}$ A complete description of the accounts is available in Guide to the Flow of Funds Accounts, Board of Governors of the Federal Reserve System, Washington, D.C. The Z.1 statistical release is available in printed form and on the Board's public web site at www.federalreserve.gov/releases/Z1.
} 
0.16 and -0.10 , respectively. These univariate statistics suggest that REIT mutual fund flows may drive subsequent equity security offerings, but that security offerings are not associated with increased flows to mutual funds. This is consistent with the notion that net new investments in REIT mutual funds create an opportunity for additional initial and secondary equity offerings.

\section{The Relation between Flows and Returns}

Although the unconditional results discussed in the previous section suggest there is a relation between capital flows and returns (or NAV premiums), they do not clearly depict the structure of the relation and do not control for other factors likely to influence flows and returns (or NAV premiums). We seek to answer two questions. First, do REIT mutual fund flows predict industry-level REIT returns over and above the predictions of lagged returns? Second, do returns predict fund flows over and above the predictions of lagged flows? To address these questions, we would prefer to base our analysis on an economic theory that captures the dynamic relation between capital flows and returns. However, given the absence of such a theory, we rely on vector autoregressions (VARs) to characterize the behavior of important variables.

In its simplest form, a VAR model is composed of a system of regressions in which a set of dependent variables are expressed as linear functions of their own and each other's lagged values, and possibly some other independent variables. For example, without loss of generality, consider the following two-variable, one-period lag VAR model:

$$
\begin{aligned}
& Y_{t}=a_{1}+b_{1} Y_{t-1}+c_{1} Z_{t-1}+e_{1 t} \\
& Z_{t}=a_{2}+b_{2} Z_{t-1}+c_{2} Y_{t-1}+e_{2 t} .
\end{aligned}
$$

VARs have proven especially useful for forecasting systems of interrelated time series variables. In more technical terms, a vector autoregression model is the unconstrained reduced form of a dynamic simultaneous equations model.

In general terms, an unrestricted $\mathrm{p}^{\text {th }}$-order Gaussian VAR model can be represented as:

$$
Y_{t}=\mu+\Phi_{1} Y_{t-1}+\Phi_{2} Y_{t-2}+\ldots+\Phi_{k} Y_{t-p}+e_{t},
$$

where $\mathrm{Y}_{\mathrm{t}}$ is a vector of variables, $\mu$ is a $p \times 1$ vector of intercepts, $\Phi_{1}, \Phi_{2}, \ldots, \Phi_{\mathrm{k}}$ are $p \times p$ matrices of parameters with all eigenvalues of $\Phi$ having moduli less than one so that the VAR is stationary, and $e_{t}$ is a vector of uncorrelated structural shocks $[\sim N I D(0, \Omega)]$. In a bivariate framework of only fund flows and returns (or NAV premiums), the diagnol coefficients of $\Phi$ 
represent conditional momentum in flows and returns, while the off-diagnol coefficients of $\Phi$ represent conditional positive feedback trading (flows following returns) and conditional anticipation effects (returns following flows). The off-diagnol elements of $\Omega$ capture the priceimpact effect of flows on returns.

We obtain maximum likelihood estimates of $\Phi$ and $\Omega$ using iterated least squares. The lag-length of the VAR is chosen by looking at the AIC and the likelihood ratio for various choices of $p$. We also use the estimates of $\Phi$ to form impulse response functions, which provide the time path of the short-run dynamic relationships from a shock to the variables in the system. In particular, we compute impulse responses from a one standard deviation flow shock and examine the effects on flows and returns. We then compute impulse responses from a one standard deviation return shock and examine the effects on flows and returns. Finally, we examine the forecast variance decompositions from the system to provide the forecast error variance explained by variations in the variables.

As a robustness check on the unrestricted VAR models, we also examine various restricted VAR models. In particular, we estimate structural VAR models in which we impose various structural assumptions about the causality of flows and returns. Because a problem arises with the VAR framework if the variables in the system are non-stationary, as an additional robustness check we also examine vector error-correction (VEC) models in cases where the data are nonstationary. ${ }^{13}$

A vector error-correction (VEC) model is similar to a VAR model, except the VEC model is designed for use with non-stationary time series (see, for example, Hamilton, 1994). In particular, the VEC model is more appropriate if the variables in the VAR system are integrated of order one or more (i.e., are non-stationary). In this case, the VAR estimates and inferences drawn from them are subject to the problems of regressions involving non-stationary variables. The VEC model, on the other hand, is a restricted VAR model designed for use with non-

\footnotetext{
${ }^{13}$ In general, a series is non-stationary if its mean, autocovariances, or other higher moments are time dependent. For example, if the mean of a series varies with respect to time, it is likely to be non-stationary. Simply stated, the test for a unit root (i.e., non-stationarity) in a time-series is the test that a regression of a series on itself lagged one period yields a coefficient of one. This test is complicated by several features arising from the non-stationarity of the series under the null hypothesis. In a well-known paper, Dickey and Fuller (1979) suggest a method for computing a test for a unit root in a time-series. Since then, a large literature on unit root tests has appeared with alternative tests that are generally variations of the Dickey-Fuller test.
} 
stationary series that are cointegrated. A group of non-stationary time series is cointegrated if there is a linear combination of them that is stationary. These cointegrating relations are incorporated into the VEC. For example, consider the following two-variable VEC with nonstationary time series:

$$
\begin{aligned}
& \Delta \mathrm{Y}_{\mathrm{t}}=\mathrm{a}_{1}+\mathrm{b}_{1} \Delta \mathrm{Y}_{\mathrm{t}-1}+\mathrm{c}_{1} \Delta \mathrm{Z}_{\mathrm{t}-1}+\alpha_{1}\left(\mathrm{Y}_{\mathrm{t}-1}-\beta \mathrm{Z}_{\mathrm{t}-1}\right)+\mathrm{e}_{1 \mathrm{t}} \\
& \Delta \mathrm{Z}_{\mathrm{t}}=\mathrm{a}_{2}+\mathrm{b}_{2} \Delta \mathrm{Z}_{\mathrm{t}-1}+\mathrm{c}_{2} \Delta \mathrm{Y}_{\mathrm{t}-1}+\alpha_{2}\left(\mathrm{Y}_{\mathrm{t}-1}-\beta \mathrm{Z}_{\mathrm{t}-1}\right)+\mathrm{e}_{2 \mathrm{t}},
\end{aligned}
$$

where all terms involving $\Delta$ (i.e., first differences) are stationary. This two-variable error correction model is a bivariate VAR in first differences augmented by the error-correction terms $\alpha_{1}\left(\mathrm{Y}_{\mathrm{t}-1}-\beta \mathrm{Z}_{\mathrm{t}-1}\right)$ and $\alpha_{2}\left(\mathrm{Y}_{\mathrm{t}-1}-\beta \mathrm{Z}_{\mathrm{t}-1}\right)$ from the cointegrating relation. In general, the $\mathrm{k}^{\text {th }}$ order vector error-correction model can be represented by the following system:

$$
\Delta X_{t}=\mu+\Gamma_{1} \Delta X_{t}-1+\Gamma_{2} \Delta X_{t}-2+\ldots+\Gamma_{k}-1 \Delta X_{t}-k+1+\Pi X_{t}-k+e_{t},
$$

where $\mathrm{X}_{\mathrm{t}}$ is a vector of $p I(1)$ variables, $\mu$ is a $p \times 1$ vector of intercepts, $\Gamma_{1}, \Gamma_{2}, \Gamma_{\mathrm{k}}, \Pi$ are $p \times p$ matrices of parameters, $e_{t}$ is a vector of uncorrelated structural shocks $[\sim N I D(0, \Omega)], \Delta$ is a difference operator, and $I(1)$ is integrated of order one (i.e., first-difference stationary). In the above VEC system, the coefficient matrix $\Pi$ provides information about the long-run relations among the variables, while the $\Gamma$ 's provide information on short-run relations. Using Johansen's (1988) method, we obtain estimates of the long-run relationships.

\section{Unrestricted Vector Autoregressive Results}

In this section, we examine the conditional covariation results using three unrestricted VAR models: a bivariate model, a four-factor model, and a seven-factor model. The bivariate model consists of capital flows to dedicated REIT mutual funds and aggregate REIT returns (or NAV premiums). Next, using our four-factor model, we seek to determine whether the relations we uncover in our bivariate model exist after controlling for interest rates and dividend yield spreads. As discussed earlier, the dividend yield spread is frequently hypothesized to be an important determinant of investor demand for REIT stocks. Finally, we estimate an augmented version of the four-factor model that includes the three Fama-French risk factors $\left(R_{M K T}-R_{f}, S M B\right.$, and $H M L$ ). The results from these three models provide conditional evidence on the influence of REIT returns on fund flows, and vice versa, as well as the dynamics of the relationship. 
We report the VAR model estimates for the monthly data in Table 4. The data support the use of four monthly lags for each of the specifications, although we only report the coefficient estimates for the first two lags. The first two columns in Table 4 contain the results for the bivariate model. The remaining four columns display the results for the four-factor and sevenfactor models, respectively. Looking first at the results for the flow (RFLOWS) equations, we find that current flows are significantly positively related in all three specifications to flows in month $t-1$ and month $t$-2. These results suggest significant positive momentum in REIT mutual fund flows. We also find that monthly fund flows are positively related to returns in month $t-1$, suggesting that REIT mutual fund investors chase returns. This result is consistent with the findings of Edwards and Zhang (1998), Fortune (1998), Cha and Lee (2001), Karceski (2003), and Edelen and Warner (2001). The three model specifications are able to explain 32-36 percent of the variation in monthly fund flows.

Turning to the three $R_{R E I T}$ equations in Table 4, we find that fund flows do not significantly influence subsequent REIT returns. This result is consistent with the findings of Edwards and Zhang (1998) and Cha and Lee (2001). Moreover, we find that REIT returns are not generally influenced by previous REIT returns. Although not reported in Table 4, the coefficient estimates for the interest rate and REIT dividend yield spread variables are not significant in either the four-factor or seven-factor specifications. Overall, the bivariate and fourfactor models are able to explain little of the monthly variation in REIT returns.

Interestingly, we find that the market risk premium $\left(R_{M K T}-R_{f}\right)$ and $H M L$ have a significant and positive impact on REIT returns in the seven-factor model. As noted earlier, $H M L$ captures value-versus-growth effects in general stock market returns. The positive coefficient on $R_{M K T}-R_{f}$ captures the correlation of REIT returns with a broad-based measure of stock performance, as measured by the CRSP value-weighted return index. However, even after controlling for the market risk premium, the coefficient on $H M L$ is positive and statistically significant. This suggests that market participants view REIT stocks, in the aggregate, as small cap value stocks. Thus, when investor sentiment shifts away from value (high dividend yielding) stocks to growth stocks, as it did during the high tech boom of the late 19990s, REIT returns are negatively affected. Conversely, when stock investors rotate out of growth stocks and into value stocks, REIT returns are positively affected. 
In Panel A of Figure 5, we plot the impulse responses of a generalized one standard deviation innovation in monthly REIT flows and returns. ${ }^{14}$ The impulse responses are based on the seven-factor unrestricted VAR model estimates. The top left graph, which depicts the response of monthly relative fund flows to a one standard deviation return shock, suggests a persistent effect of returns on flows. The return shock produces an approximate five- to ninemonth change in flows, which dissipates to zero thereafter. Second, the top right graph depicts the response of fund flows to a flows shock. This shock results in a large initial change in flows, which dissipates quickly to zero thereafter. When we shock aggregate REIT returns, we find a temporary increase in subsequent REIT returns, which then dissipate to zero after one month (bottom left graph). Finally, consistent with our earlier findings, a shock in fund flows does not have a measurable impact on REIT returns (bottom right graph). ${ }^{15}$

In Panels $\mathrm{A}$ and $\mathrm{B}$ of Table 5, we report the variance decomposition of monthly REIT fund flows and returns, respectively. In Panel A, we document that in the first period of the forecast horizon for REIT fund flows, $100 \%$ of the squared prediction error in flows is explained by variation in flows. At horizons up to ten months, flows explain about $82 \%$ of the forecast error variance. At almost $8.5 \%$, returns explain the next largest amount of the forecast error variance, while the other variables explain the remaining amount. Interestingly, turning to Panel $\mathrm{B}$, we document that in the first period of the forecast horizon for REIT returns, returns explain $71 \%$ of the variation and flows explain the remaining $29 \%$. At horizons up to 10 months, the explanation of returns and flows continues to dominate at $58 \%$ and $25 \%$ respectively. The NAREIT yield spread, $R_{M K T}-R_{f}$, and $H M L$ explain approximately $15 \%$ of the remaining variation.

\section{Weekly Flows and REIT Returns}

As previously discussed, the use of monthly data may mask some of the dynamic relation between mutual fund flows and returns; weekly data should allow for greater precision in determining the contemporaneous versus non-contemporaneous components of covariance between fund flows and returns. Our weekly VAR estimates for the bivariate, four-factor, and seven-factor model specifications are presented in Table 6. Looking first at the results for the

\footnotetext{
${ }^{14}$ As described in Pesaran and Shin (1998), generalized impulses do not depend on the VAR ordering. However, as a robustness check, we also examined various Cholesky orderings and obtained similar results.

${ }^{15}$ The impulse response function patterns are also generally similar using the net asset value premiums in place of the REIT returns.
} 
flow equations, we find that the estimated coefficients on fund flows in week $t-1$ are positive and highly significant (t-statistics greater than 6) in all three model specifications. Moreover, the coefficients on flows in week $t-2$ and week $t$-3 are also positive and significant at the 1 percent level. By week $t-4$, the impact on contemporaneous flows is no longer significant at the 5 percent level.

We found in our monthly analysis that REIT fund flows in month $t$ are positively related to industry-wide returns in month $t$-1, which is suggestive of return chasing behavior. Our weekly estimates clarify this result. The estimated coefficients on week $t-1$ returns are positive and highly significant in all three model specifications. However, week $t-2$ returns have no effect on current flows, suggesting the effect of returns on flows is concentrated in a one week period. Interestingly, weekly fund flows are well explained by the bivariate model; the additional variables included in the four-factor and seven-factor specifications do not increase the adjusted R-squared.

Turning to the three $R_{R E I T}$ equations in Table 6, we find that fund flows in prior weeks do not significantly influence current REIT returns. This result is consistent with our monthly results that fund flows do not drive subsequent returns. Table 6 also reveals that week $t-2$ returns are negatively and significantly related to contemporaneous returns. This lagged price reversal was not detectible in the monthly data. Similar to our monthly results, the REIT dividend yield spread plays no role in explaining weekly flows or returns. In our monthly seven-factor model, the coefficient on the lagged market risk premium $\left(R_{M K T}-R_{f}\right)$ was positive and significant. The corresponding results in Table 6 indicate that the monthly risk premium effect on REIT returns is concentrated in week $t-2$.

Several other differences in the monthly and weekly results are worth noting. First, the estimated coefficient on the lagged risk-free interest rate is negative and statistically significant in both the four-factor and seven-factor weekly return models. The coefficient on the risk-free rate was never significant in the monthly estimations. Second, although we still find a role for lagged HML in explaining returns, the effect is greatly attenuated relative to the monthly estimates. Moreover, the effect of HML on returns is concentrated in week $t-2$. Finally, similar to the monthly results, lagged REIT returns, lagged market risk premiums, and lagged HML returns all 
play a role in explaining weekly REIT returns, though the effect is concentrated at lag $t$ - 2 with the weekly results.

In Panel B of Figure 5, we plot the impulse responses of a generalized one standard deviation innovation in weekly REIT flows and returns. These response functions are based on the seven-factor unrestricted VAR model estimates. The top left graph depicts the response of weekly REIT fund flows to a one standard deviation return shock. The return shock produces a significant two week change in flows, which dissipates significantly in week 3 and then declines toward zero in weeks 4 through 10. The top right graph depicts the response of fund flows to a flows shock. This shock produces a large change in flows in the subsequent week. The flow response is greatly reduced, but still positive, in week 2 ; it then slowly dissipates toward zero in weeks three through 10.

When we shock aggregate REIT returns, we find a sharp temporary increase in subsequent REIT returns (bottom left graph). This initial increase is reversed in weeks 2 and 3 as returns turn slightly negative. The effect of a return shock on returns then dissipates to zero by week four. Finally, consistent with our earlier findings, a shock in fund flows has no measurable impact on subsequent REIT returns (bottom right graph).

\section{Monthly Flows and REIT NAV Premiums}

As an alternative to the use of REIT returns, we report our VAR model estimates using REIT NAV premiums in Table 7. Turning first to the results for the flow equations, we again find that contemporaneous monthly flows are significantly positively related to flows in month $t$ 1 in all three specifications. However, contemporaneous flows are not related to month $t$ - 2 flows. We also find that fund flows are positively related to net asset value premiums in month $t$ - 1 , but not to month $t$-2 premiums. The three RFLOWS specifications are able to explain 36-39 percent of the variation in monthly fund flows.

Turning to the PNAV equations, we find that fund flows in prior months do not significantly influence NAV premiums. As noted in the descriptive statistics section earlier, NAV premiums have a significant first order autoregressive component. We see this result again in the large (0.85 to 0.93 ) and highly significant coefficient estimates for PNAV in month $t$ - 1 and in the explanatory power of the PNAV equations $\left(\mathrm{R}^{2}=0.87\right.$ in all three specifications $)$. Although not reported in Table 7 , the coefficient estimates on the interest rate and REIT dividend yield 
spread variables are not significant in either the four-factor or seven-factor specifications. Similar to the monthly return estimations, the one-week lags of the market risk premium $\left(R_{M K T}-R_{f}\right)$ and $H M L$ have a significant and positive impact on net asset value premiums.

\section{Robustness Checks, Restricted VAR Models, and VEC Models}

We also performed various robustness checks on the conditional relationship between REIT flows and returns using both monthly and weekly data. In particular, we separated REIT flows into expected and unexpected components. As a first-pass, we regressed REIT flows on lagged REIT flows, lagged REIT returns and the additional variables from our seven-factor model specification. In a second-pass, we then regressed REIT returns on the expected and unexpected components of REIT flows from the first-pass. We found that the REIT returns were affected by the unexpected REIT flows, whereas expected REIT flows had no affect on REIT returns. This result is also consistent with the findings reported by Warther (1995).

As additional robustness checks, we also estimated structural VARs (i.e., restricted VARs) and VEC models. In our estimation of the structural VARs, we impose the identifying restriction that current REIT returns are related to current flows as well as to both past returns and flows. This assumption would hold if market makers perceive current flows to contain information about value. Interestingly, we find that current flows are significant in explaining current returns, but there is also a subsequent reversion to over half of this effect one period later. Furthermore, this positive effect arises from the unexpected component of flows, while the

expected component is insignificant. Similar to our earlier reported findings, we also find that flows exhibit positive momentum.

As discussed earlier, a potential problem arises with the VAR framework if the variables in the system are non-stationary. Therefore, to assess the stationarity of the variables, we also performed both Dickey-Fuller and Phillips-Perron unit root tests (with and without trends). We could not reject the null hypothesis of a unit root at the 5\% significance level for the NAV premium data in each case, whereas we could only reject the unit root hypothesis for the REIT flow data at the $1 \%$ level using the Dickey-Fuller tests with a trend. Using Johansen's (1988) method, we first obtained the number of cointegrating vectors (rank of $\Pi$ ) and then the parameter estimates using the VEC model. The results of Johansen's (trace) cointegration tests marginally 
indicate the existence of one cointegrating vector at the $10 \%$ level for both the REIT return and NAV premium specifications. Though not reported, the results from the VEC model with the cointegrating vector suggest that there is a long-run positive, but marginal relation both between flows and returns as well as flows and NAV premiums. The short-run dynamics from the VEC estimates are also very similar to the VAR model estimates reported earlier.

\section{Conclusion}

This study examines the interrelationships and short and long-run dynamics between capital flows to dedicated REIT mutual funds and aggregate REIT returns. In particular, our research examines whether REIT mutual fund flows impact REIT prices and returns and whether the effect is temporary or permanent. Simultaneously, we examine whether past REIT returns influence current capital flows into dedicated REIT mutual funds.

We employ both weekly and monthly fund flow data from AMG Data Services. Our sample period, dictated by the availability of AMG's data, runs from the first week of 1992 through August of 2003. The main tool of analysis is vector autoregression (VAR). We estimate three unrestricted VAR models: a bivariate model, a four-factor model, and a seven-factor model. The bivariate model consists of REIT fund flows and aggregate REIT returns, as well as a lag structure. The four-factor model also includes short-term interest rates and the NAREIT dividend yield spread as exogenous variables. Our seven-factor model also includes the Fama-French risk factors $\left(R_{M K T}, S M B\right.$, and $\left.H M L\right)$, which have been found to have an influence on equity REIT returns.

We find consistent evidence that REIT mutual fund flows are significantly and positively related to prior industry-level returns; i.e., we find evidence of return chasing behavior on the part of REIT mutual fund investors. However, prior fund flows do not significantly influence REIT returns. We also decompose fund flows into their expected and unexpected components and estimate structural (restricted) VARs. With this specification we find evidence that contemporaneous fund flows do have an initial positive effect on returns, which is partially reversed one period later. The positive contemporaneous effect, moreover, is the result of unexpected REIT mutual fund flows; the expected portion is insignificant. As a robustness 
check, we also estimate a vector error correction (VEC) model, which produced results very similar to our VAR results.

\section{References}

Bekaert, G., and C.R. Harvey. 2000. Foreign Speculators and Emerging Equity Markets. Journal of Finance 55: 565-613.

Capozza, D. and P. Seguin. 2003. Special Issue: Real Estate Investment Trusts-Forward from the Guest Editors. Real Estate Economics 31(3): 305-312.

Cha, H.S. and B. Lee. 2001. The Market Demand Curve for Common Stocks: Evidence from Equity Mutual Fund Flows. Journal of Financial and Quantitative Analysis 36(2): 195-220.

Clayton, J., 2003. Capital Flows and Asset Values: A Review of the Literature and Exploratory Investigation in a Real Estate Context. Unpublished Working Paper, University of Cincinnati, Cincinnati, $\mathrm{OH}$.

Dickey, D. and W. Fuller. 1979. Distribution of the Estimates for Autoregressive Time Series with a Unit Root. Journal of the American Statistical Association 79(366): 427-431.

Edelen, R. M. and J. B. Warner. 2001. Aggregate Price Effects of Institutional Trading: A Study of Mutual Fund Flow Data and Market Returns. Journal of Financial Economics 59(2): 195-220.

Edwards, F. R., and X. Zhang. 1998. Mutual Fund Flows and Stock and Bond Market Stability. Journal of Financial Services Research 13(3): 257-282.

Engen, E. M. and A. Lehnert. 2000. Mutual Funds and the U.S. Equity Market. Federal Reserve Bulletin, December: 797-812.

Fama, E. and K. French, 1996. Multifactor Explanations of Asset Pricing Anomalies. Journal of Finance 51(1): 55-83.

Falzon, R. 2002. Stock Market Rotations and REIT Valuation. Prudential Real Estate Investors, October: 1-10.

Fortune, P. 1998. Mutual Funds, Part II: Fund Flows and Security Returns. New England Economic Review, Federal Reserve Bank of Boston, Jan/Feb: 3-22.

Froot, K.A., P.G.J. O'Connell, and M.S Seasholes. 2001. The Portfolio Flows of International Investors. Journal of Financial Economics 59(2): 151-194.

Goetzman, W. and M. Massa. 2003. Index Funds and Stock Market Growth. Journal of Business 76: 
Goetzman, W., M. Massa, and K.G. Rouwenhorst. 2000. Behavior Factors in Mutual Fund Flows, Yale ICF Working Paper, No. 00-14.

Hamilton, J. D. 1994. Time-series Analysis, Princeton Press.

Johansen, S. 1988. Statistical Analysis of Cointegrating Vectors. Journal of Economic

Dynamics and Control12(2-3): 231-254.

Karceski, J. 2002. Returns-Chasing Behavior, Mutual Funds, and Beta's Death. Journal of Financial and Quantitative Analysis 37(3): 559-599.

Lettau, M., and S., Ludvigson, 2001, "Resurrecting the (C)CAPM: A Cross-Sectional Test When Risk Premia are Time-Varying," Journal of Political Economy, forthcoming.

Liew, J., and M. Vassalou, 2000, "Can Book-to-Market, Size and Momentum Be Risk factors That Predict Economic Growth?," Journal of Financial Economics 57, 221-245.

Ling, D.C. and A. Naranjo. 2003. The Dynamics of REIT Capital Flows and Returns. Real Estate Economics 31(3): 405-436.

Ling, D.C. and M. Ryngaert. 1997. Valuation Uncertainty, Institutional Involvement, and the Underpricing of IPOs: The Case of REITs. Journal of Financial Economics 43(3): 433-456.

Pesaran, H. H. and Y. Shin. 1998. Generalized Impulse Response Analysis in Linear Multivariate Models. Economic Letters 58: 17-29.

Remolona, E.M., P. Kleiman, and D. Gruenstein. 1997. Market Returns and Mutual Fund Flows, Federal Reserve Bank of New York Policy Review 3(2): 33-52.

Sims, C. 1980. Macroeconomics and Reality. Econometrica 48(1), pp. 1-49.

Warther, V.A. 1995. Aggregate Mutual Fund Flows and Security Returns. Journal of Financial Economics 39: 209-235.

Warther, V.A. 1998. Has the Rise of Mutual Funds Increased Market Instability? Brookings Papers on Financial Services, The Brookings Institution. 

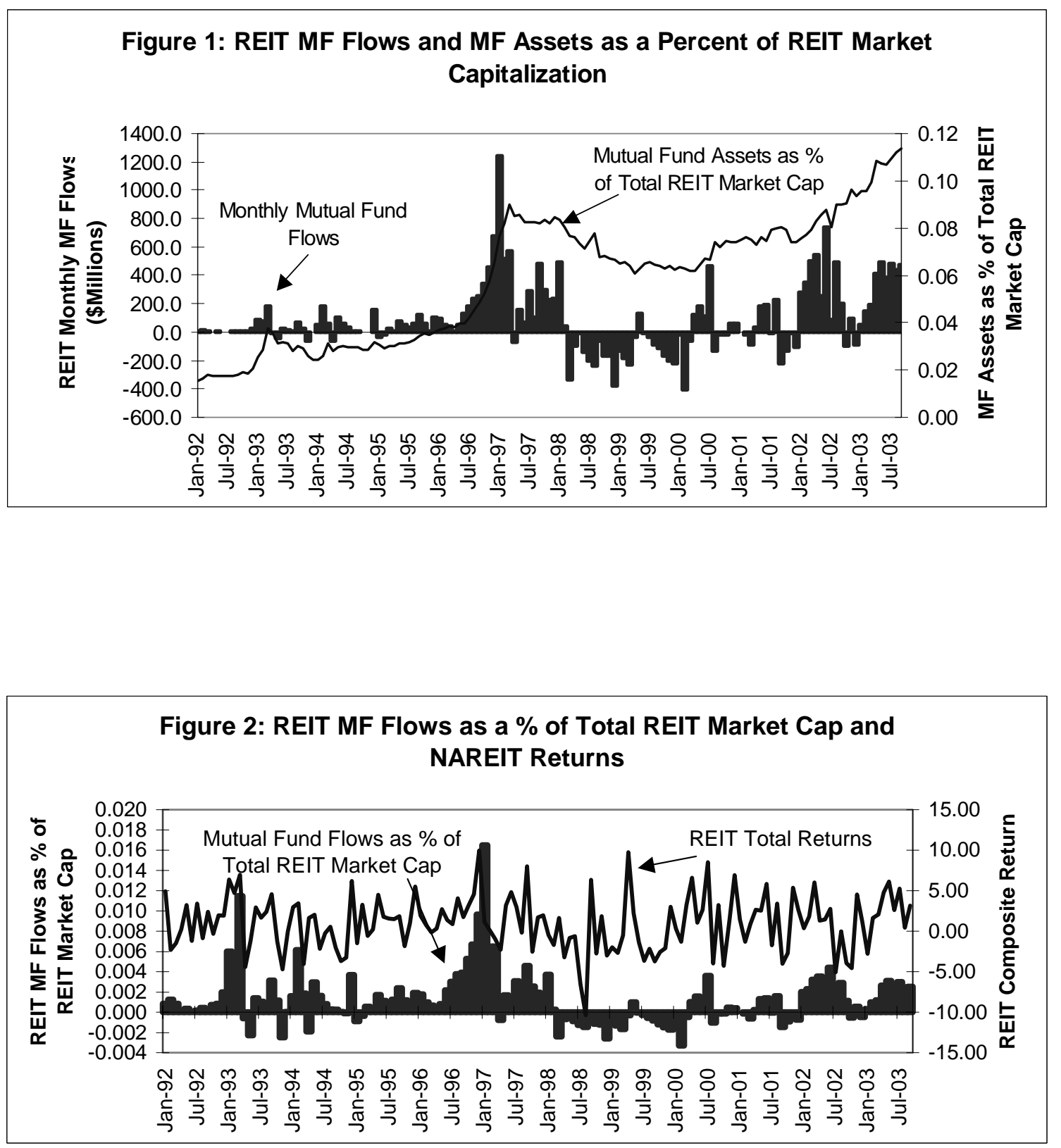

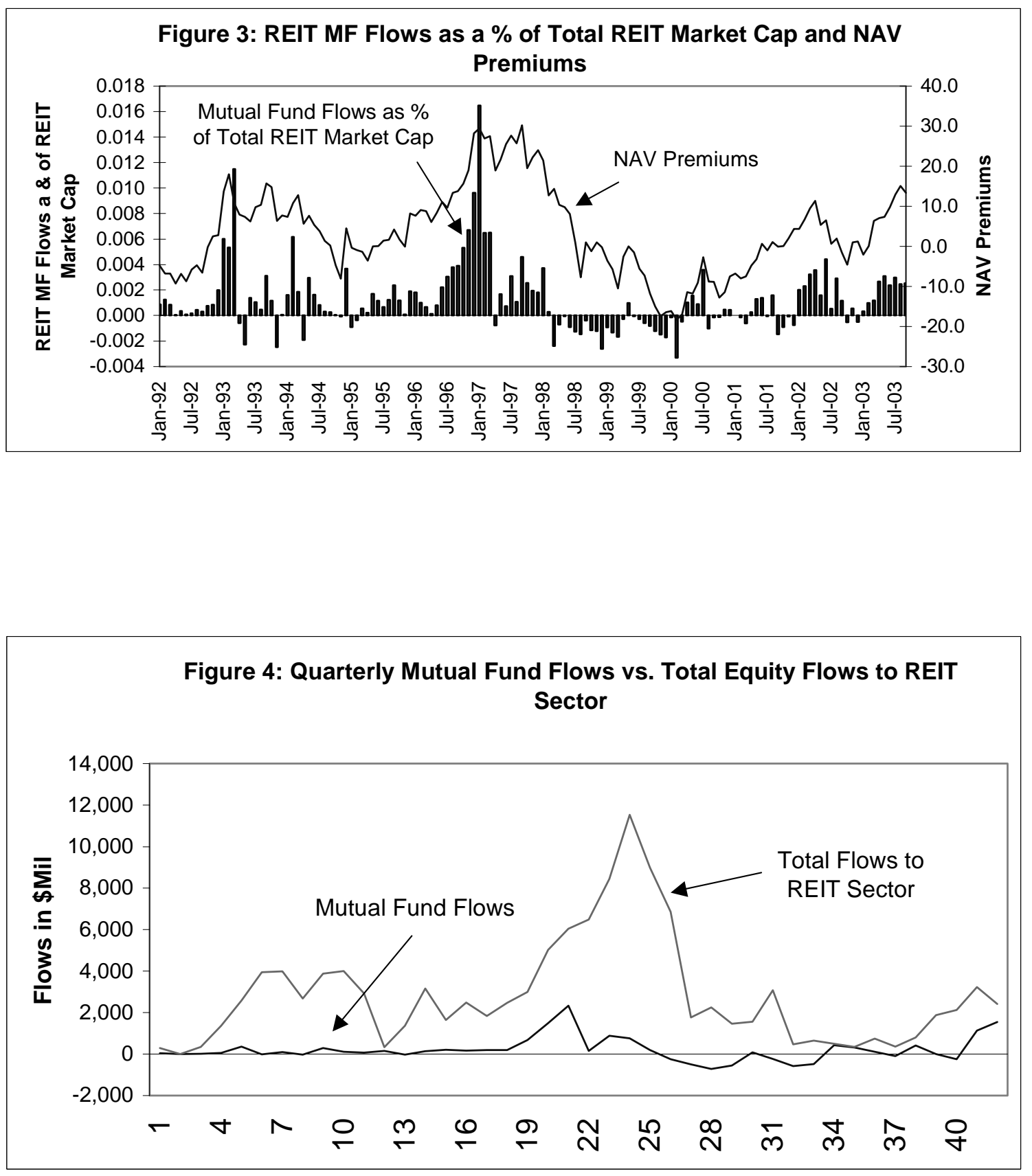


\section{Figure 5}

\section{Impulse Responses from Monthly and Weekly Vector Autoregressive Model (Seven-Factor):}

1992:01 -2003:08

Panel A: Monthly REIT Returns and Flows:

Response to Cholesky One S.D. Innovations \pm 2 S.E.
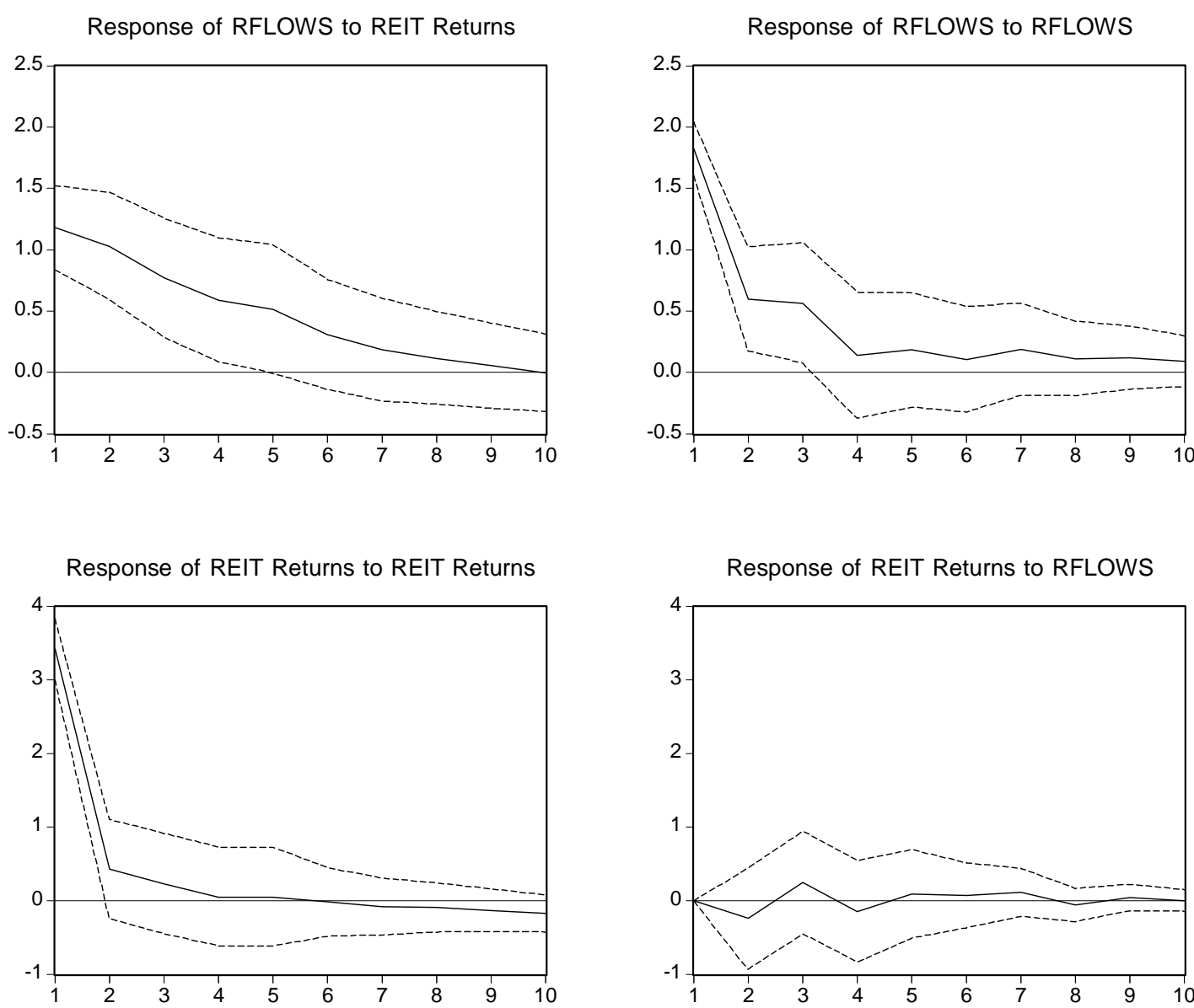

Response of REIT Returns to RFLOWS

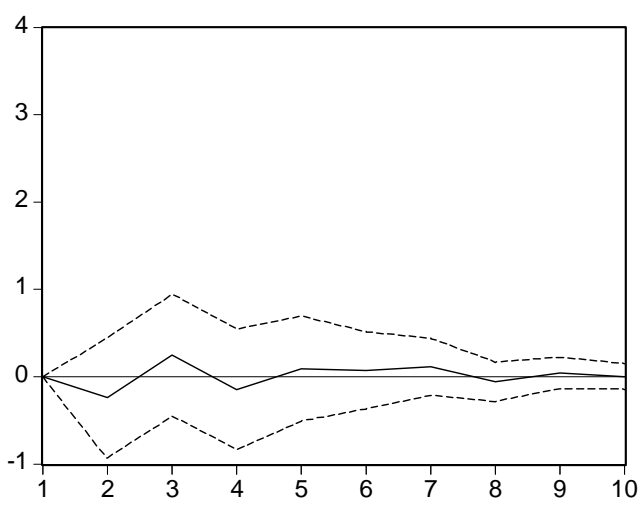




\section{Figure 5 Continued}

\section{Panel B: Weekly REIT Returns and Flows:}

Response to Cholesky One S.D. Innovations \pm 2 S.E.

Response of RFLOWS to REIT Returns

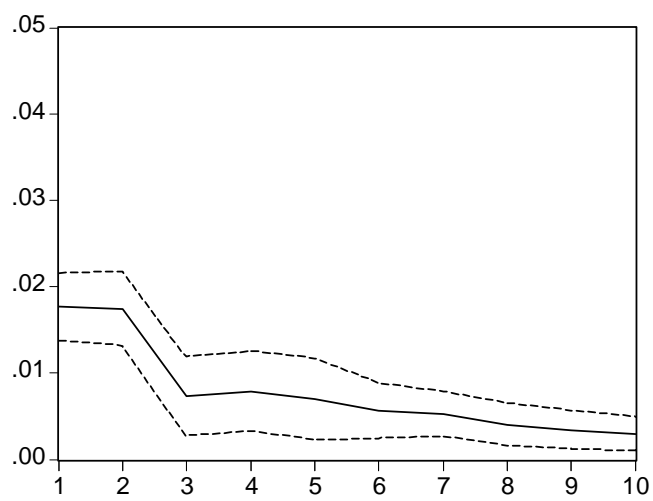

Response of REIT Returns to REIT Returns

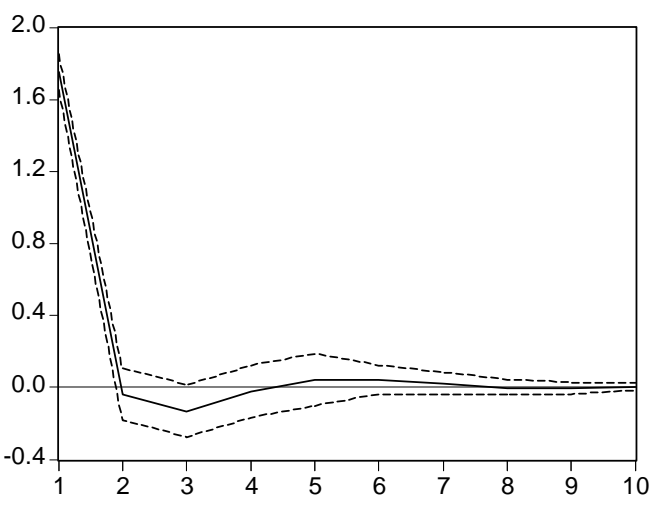

Response of RFLOWS to RFLOWS

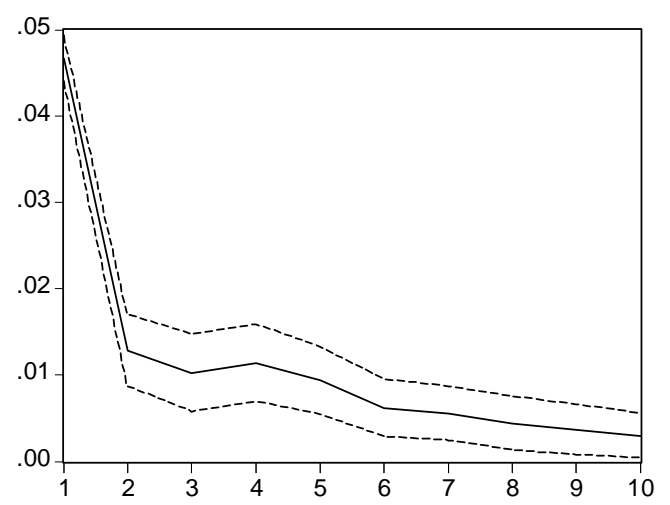

Response of REIT Returns to RFLOWS

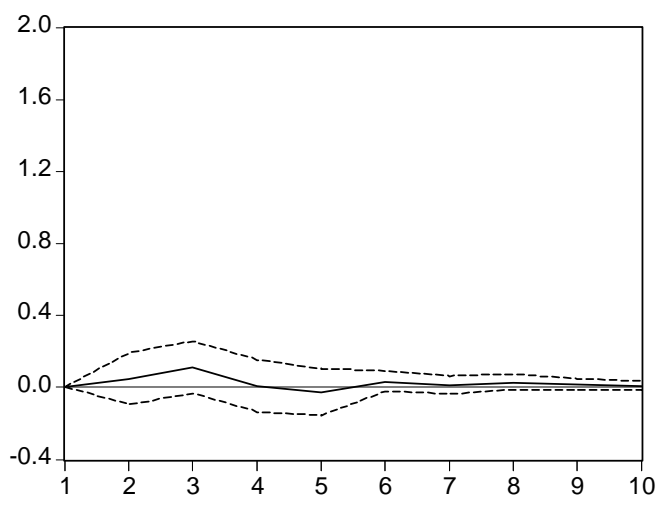


Table 1

Descriptive Statistics: 1992:01 -2003:08

\begin{tabular}{lccccc}
\hline & \multicolumn{2}{c}{ Monthly Data } & & \multicolumn{2}{c}{ Weekly Data } \\
\cline { 2 - 3 } \cline { 5 - 6 } Variables & Mean & Std. Dev. & & Mean & Std. Dev \\
\hline FLOWS & $\$ 86.2$ & $\$ 227.5$ & & $\$ 17.2$ & $\$ 52.6$ \\
RFLOWS & $0.12 \%$ & $0.003 \%$ & & $0.02 \%$ & $0.06 \%$ \\
$R_{\text {REIT }}$ & $0.98 \%$ & $3.40 \%$ & & $0.25 \%$ & $1.80 \%$ \\
$P N A V$ & $3.52 \%$ & $10.79 \%$ & & N.A. & N.A. \\
$Y L D S P$ & 1.21 & 1.11 & & 1.50 & 1.04 \\
$R_{f}$ & $0.34 \%$ & $0.12 \%$ & & $0.08 \%$ & $0.03 \%$ \\
$R_{M K T}-R_{f}$ & $0.56 \%$ & $4.38 \%$ & & $0.13 \%$ & $0.13 \%$ \\
$S M B$ & 0.31 & 3.68 & & 0.03 & 1.41 \\
$H M L$ & 0.32 & 4.45 & & 0.11 & 1.51 \\
\hline
\end{tabular}

FLOWS: AMG dedicated REIT mutual fund flows in \$millions.

RFLOWS: AMG dedicated REIT mutual fund flows as a percentage of total REIT stock market capitalization in month $t-3$ (Panel A) and week $t$-3 (Panel B).

$R_{R E I T}$ : Total return on the aggregate NAREIT Index (Panel A); weekly total returns constructed by authors from CRSP and Compustat data

PNAV: Aggregate premium of REIT shares prices divided by Green Street's estimate of industry net asset value (NAV). YLDSP: NAREIT dividend yield minus the yield on 10-year Treasury securities.

$R_{f}$ : CRSP one-month US Treasury return (Panel A) and one-week US Treasury return (Panel B) from the Federal Reserve Board.

$R_{M K T}-R_{f}$ : Total return on CRSP's value-weighted market index minus the CRSP one-month (Panel A) and one-week (Panel B) US Treasury return.

$S M B$ : Fama-French small firm minus big firm return factor.

$H M L$ : Fama-French high book to market minus low book to market return factor. 
Table 2

Contemporaneous Correlations: 1992:01 - 2003:08

Panel A: Monthly Correlations

\begin{tabular}{|c|c|c|c|c|c|c|c|c|c|}
\hline & FLOWS & RFLOWS & $R_{R E I T}$ & $Y L D S P$ & $R_{f}$ & $R_{M K T}-R_{f}$ & $S M B$ & $H M L$ & PNAV \\
\hline FLOWS & 1.00 & & & & & & & & \\
\hline RFLOWS & 0.84 & 1.00 & & & & & & & \\
\hline$R_{R E I T}$ & 0.41 & 0.45 & 1.00 & & & & & & \\
\hline$Y L D S P$ & -0.26 & -0.39 & -0.13 & 1.00 & & & & & \\
\hline$R_{f}$ & -0.18 & -0.05 & -0.01 & -0.29 & 1.00 & & & & \\
\hline$R_{M K T}-R_{f}$ & -0.04 & 0.01 & 0.33 & -0.06 & 0.04 & 1.00 & & & \\
\hline$S M B$ & 0.06 & 0.01 & 0.25 & 0.06 & -0.19 & 0.19 & 1.00 & & \\
\hline$H M L$ & 0.23 & 0.19 & 0.21 & -0.09 & 0.00 & -0.30 & -0.36 & 1.0 & \\
\hline PNAV & 0.58 & 0.60 & 0.25 & -0.58 & -0.10 & 0.15 & 0.01 & 0.08 & 1.00 \\
\hline
\end{tabular}

Panel B: Weekly Correlations

\begin{tabular}{lcccccc}
\hline & $F L O W S$ & RFLOWS & $R_{\text {REIT }}$ & $Y L D S P$ & $R_{f}$ & $R_{M K T}-R_{f}$ \\
\hline FLOWS & 1.00 & & & & & \\
RFLOWS & 0.83 & 1.00 & & & & \\
$R_{\text {REIT }}$ & 0.34 & 0.29 & 1.00 & & & \\
YLDSP & -0.26 & -0.31 & -0.05 & 1.00 & & \\
$R_{f}$ & -0.06 & 0.02 & -0.02 & -0.39 & 1.00 & 1.00 \\
$R_{M K T}-R_{f}$ & 0.11 & 0.07 & 0.55 & -0.02 & -0.01 & -0.01 \\
SMB & 0.02 & -0.02 & 0.07 & 0.05 & -0.11 & -0.00 \\
$H M L$ & 0.09 & 0.11 & -0.08 & -0.07 & 0.04 & -0.357 \\
\hline
\end{tabular}

FLOWS: AMG dedicated REIT mutual fund flows in \$millions.

RFLOWS: AMG dedicated REIT mutual fund flows as a percentage of total REIT stock market capitalization in month $t$-3 (Panel A) and week $t$-3 (Panel B). $R_{R E I T}$ : Total return on the aggregate NAREIT Index (Panel A); weekly total returns constructed by authors from CRSP and Compustat data $P N A V$ : Aggregate premium of REIT shares prices divided by Green Street's estimate of industry net asset value (NAV).

$Y L D S P$ : NAREIT dividend yield minus the yield on 10-year Treasury securities.

$R_{f}$ : CRSP one-month US Treasury return (Panel A) and one-week US Treasury return (Panel B) from the Federal Reserve Board.

$R_{M K T}-R_{f}$ : Total return on CRSP's value-weighted market index minus the CRSP one-month (Panel A) and one-week (Panel B) US Treasury return.

$S M B$ : Fama-French small firm minus big firm return factor.

$H M L$ : Fama-French high book to market minus low book to market return factor. 
Table 3

Lead and Lag Correlations: 1992:01 - 2003:08

Panel A: Monthly Correlations

\begin{tabular}{|c|c|c|c|c|c|c|c|c|c|}
\hline & $R F L O W S_{t-1}$ & RFLOWS & $R F L O W S_{t+1}$ & $R_{R E I T(t-1)}$ & $R_{R E I T}$ & $R_{R E I T(t+1)}$ & $P N A V_{t-1}$ & PNAV & $P N A V_{t+1}$ \\
\hline$R F L O W S_{t-1}$ & 1.00 & & & & & & & & \\
\hline RFLOWS & 0.57 & 1.00 & & & & & & & \\
\hline$R F L O W S_{t+1}$ & 0.43 & 0.58 & 1.00 & & & & & & \\
\hline$R_{R E I T(t-1)}$ & 0.45 & 0.39 & 0.26 & 1.00 & & & & & \\
\hline$R_{R E I T}$ & -0.01 & 0.45 & 0.39 & 0.08 & 1.00 & & & & \\
\hline$R_{R E I T(t+1)}$ & 0.05 & 0.00 & 0.45 & 0.04 & 0.09 & 1.00 & & & \\
\hline$P N A V_{t-1}$ & 0.60 & 0.48 & 0.39 & 0.26 & -0.01 & -0.03 & 1.00 & & \\
\hline PNAV & 0.59 & 0.60 & 0.49 & 0.26 & 0.26 & -0.01 & 0.93 & 1.00 & \\
\hline$P N A V_{t+1}$ & 0.53 & 0.56 & 0.60 & 0.23 & 0.27 & 0.26 & 0.88 & 0.93 & 1.00 \\
\hline
\end{tabular}

Panel B: Weekly Correlations

\begin{tabular}{lcccccc}
\hline & RFLOWS & RFLOWS & RFLOWS & $R_{\text {REIT }(t-1)}$ & $R_{\text {REIT }}$ & $R_{\text {REIT }(t+1)}$ \\
\hline RFLOWS & 1.00 & & & & & \\
RFLOWS & 0.54 & 1.00 & & & & \\
RFLOWS & 0.44 & 0.54 & 1.00 & & & \\
$R_{\text {REIT }(t-1)}$ & 0.29 & 0.30 & 0.14 & 1.00 & & 1.00 \\
$R_{\text {REIT }}$ & 0.02 & 0.29 & 0.30 & 0.01 & 0.01 & 1.00 \\
$R_{\text {REIT }(t+1)}$ & 0.04 & 0.02 & 0.29 & -0.06 & & \\
\hline
\end{tabular}

FLOWS: AMG dedicated REIT mutual fund flows in \$millions.

RFLOWS: AMG dedicated REIT mutual fund flows as a percentage of total REIT stock market capitalization in month $t-3$ (Panel A) and week $t-3$ (Panel B).

$R_{\text {REIT }}$ : Total return on the aggregate NAREIT Index (Panel A); weekly total returns constructed by authors from CRSP and Compustat data

PNAV: Aggregate premium of REIT shares prices divided by Green Street's estimate of industry net asset value (NAV).

YLDSP: NAREIT dividend yield minus the yield on 10-year Treasury securities.

$R_{f}$ : CRSP one-month US Treasury return (Panel A) and one-week US Treasury return (Panel B) from the Federal Reserve Board.

$R_{M K T}-R_{f}$ : Total return on CRSP's value-weighted market index minus the CRSP one-month (Panel A) and one-week (Panel B) US Treasury return.

$S M B$ : Fama-French small firm minus big firm return factor.

$H M L$ : Fama-French high book to market minus low book to market return factor. 
Table 4

Monthly Vector Autoregressive Model Estimates: 1992:01 - 2003:08

\begin{tabular}{|c|c|c|c|c|c|c|}
\hline \multirow[t]{2}{*}{ Variables } & \multicolumn{2}{|c|}{ Bivariate Model } & \multicolumn{2}{|c|}{ Four-Factor Model } & \multicolumn{2}{|c|}{ Seven-Factor Model } \\
\hline & RFLOWS & $\mathrm{R}_{\text {REIT }}$ & RFLOWS & $\mathrm{R}_{\mathrm{REIT}}$ & RFLOWS & $\mathrm{R}_{\text {REIT }}$ \\
\hline Constant & $\begin{array}{c}0.32 \\
(1.51)\end{array}$ & $\begin{array}{c}0.91 * * * \\
(2.58)\end{array}$ & $\begin{array}{c}1.13 \\
(1.45)\end{array}$ & $\begin{array}{c}0.02 \\
(0.02)\end{array}$ & $\begin{array}{c}1.22 \\
(1.41)\end{array}$ & $\begin{array}{c}0.16 \\
(0.12)\end{array}$ \\
\hline RFLOWS (-1) & $\begin{array}{c}0.33 * * * \\
(3.14)\end{array}$ & $\begin{array}{c}-0.18 \\
(-1.06)\end{array}$ & $\begin{array}{c}0.32 * * * \\
(2.95)\end{array}$ & $\begin{array}{c}-0.11 \\
(-0.64)\end{array}$ & $\begin{array}{c}0.35 * * * \\
(2.96)\end{array}$ & $\begin{array}{c}-0.03 \\
(-0.17)\end{array}$ \\
\hline RFLOWS (-2) & $\begin{array}{c}0.25^{* *} \\
(2.20)\end{array}$ & $\begin{array}{c}0.21 \\
(1.14)\end{array}$ & $\begin{array}{c}0.24 * * \\
(2.08)\end{array}$ & $\begin{array}{c}0.20 \\
(1.07)\end{array}$ & $\begin{array}{l}0.22 * \\
(1.75)\end{array}$ & $\begin{array}{c}0.13 \\
(0.68)\end{array}$ \\
\hline $\mathrm{R}_{\text {REIT }}(-1)$ & $\begin{array}{c}0.19 * * * \\
(3.01)\end{array}$ & $\begin{array}{c}0.15 \\
(1.44)\end{array}$ & $\begin{array}{c}0.25 * * * \\
(3.20)\end{array}$ & $\begin{array}{c}0.28 * * \\
(2.25)\end{array}$ & $\begin{array}{c}0.23 * * \\
(2.40)\end{array}$ & $\begin{array}{c}0.13 \\
(0.83)\end{array}$ \\
\hline $\mathrm{R}_{\text {REIT }}(-2)$ & $\begin{array}{c}-0.01 \\
(-0.13)\end{array}$ & $\begin{array}{c}0.00 \\
(0.03)\end{array}$ & $\begin{array}{c}0.02 \\
(0.20)\end{array}$ & $\begin{array}{c}-0.03 \\
(-0.25)\end{array}$ & $\begin{array}{c}0.10 \\
(0.06)\end{array}$ & $\begin{array}{c}-0.00 \\
(-0.02)\end{array}$ \\
\hline $\mathrm{R}_{\mathrm{MKT}}-\mathrm{R}_{\mathrm{f}}(-1)$ & & & & & & $\begin{array}{c}0.22 * * \\
(2.43)\end{array}$ \\
\hline HML(-1) & & & & & & $\begin{array}{c}0.23 * * \\
(2.35)\end{array}$ \\
\hline Adj. R-squared & 0.36 & -0.03 & 0.35 & -0.01 & 0.32 & 0.21 \\
\hline
\end{tabular}

(t-statistics in parentheses: $* * * * * * ; 1 \%, 5 \%$, and $10 \%$ significance levels respectively)

We estimate the following unrestricted VAR model:

$$
Y_{t}=\mu+\Phi_{1} Y_{t-1}+\Phi_{2} Y_{t-2}+\ldots+\Phi_{k} Y_{t-p}+e_{t},
$$

where $Y_{\mathrm{t}}$ is a vector of variables, $\mu$ is a $p \times 1$ vector of intercepts, $\Phi_{1}, \Phi_{2}, \ldots, \Phi_{\mathrm{k}}$ are $p \times p$ matrices of parameters with all eigenvalues of $\Phi$ having moduli less than one so that the VAR is stationary, and $e_{t}$ is a vector of uncorrelated structural shocks $[\sim N I D(0, \Omega)]$. We obtain maximum likelihood parameter estimates using iterated least squares. The lag-length of the VAR is chosen by looking at the AIC and the likelihood ratio for various choices of $p$. The bivariate model consists of monthly REIT mutual fund flows relative to the total stock market capitalization of the NAREIT universe of REITs lagged three months $(R F L O W S)$ and REIT returns $\left(R_{R E I T}\right)$. The four-factor model also includes returns on one-month Treasury securities $\left(R_{f}\right)$ and the NAREIT dividend yield spread (YLDSP). The seven-factor model adds the Fama-French factors $\left(R_{M K T}-R_{f}, S M B\right.$, and $\left.H M L\right)$. 
Table 5

Variance Decomposition of Relative REIT Flows and Returns (Seven-Factor Model)

Panel A: Variance Decomposition of Relative Equity REIT Flows

\begin{tabular}{|c|c|c|c|c|c|c|c|c|}
\hline Period & S.E. & $\mathrm{R}_{\text {REIT }}$ & RFLOWS & $\mathrm{R}_{\mathrm{f}}$ & YLDSP & $R_{M K T}-R_{f}$ & SMB & HML \\
\hline 1 & 2.17 & 0.00 & 100.00 & 0.00 & 0.00 & 0.00 & 0.00 & 0.00 \\
\hline 2 & 2.50 & 4.63 & 93.32 & 0.36 & 1.10 & 0.36 & 0.19 & 0.04 \\
\hline 3 & 2.72 & 5.48 & 89.96 & 0.76 & 1.62 & 0.68 & 0.42 & 1.08 \\
\hline 4 & 2.80 & 7.39 & 86.90 & 1.56 & 2.01 & 0.64 & 0.45 & 1.06 \\
\hline 5 & 2.89 & 8.30 & 84.06 & 1.88 & 1.99 & 2.08 & 0.53 & 1.16 \\
\hline 6 & 2.92 & 8.59 & 83.08 & 2.25 & 2.11 & 2.19 & 0.63 & 1.13 \\
\hline 7 & 2.94 & 8.50 & 82.61 & 2.58 & 2.22 & 2.34 & 0.63 & 1.12 \\
\hline 8 & 2.95 & 8.44 & 82.19 & 2.74 & 2.20 & 2.63 & 0.68 & 1.11 \\
\hline 9 & 2.96 & 8.41 & 82.07 & 2.83 & 2.21 & 2.68 & 0.68 & 1.11 \\
\hline 10 & 2.96 & 8.43 & 81.97 & 2.90 & 2.22 & 2.68 & 0.69 & 1.11 \\
\hline
\end{tabular}

Panel B: Variance Decomposition of REIT Returns:

\begin{tabular}{|c|c|c|c|c|c|c|c|c|}
\hline Period & S.E. & $\mathrm{R}_{\mathrm{REIT}}$ & RFLOWS & $\mathrm{R}_{\mathrm{f}}$ & YLDSP & $\mathrm{R}_{\mathrm{MKT}}-\mathrm{R}_{\mathrm{f}}$ & SMB & HML \\
\hline 1 & 3.42 & 70.53 & 29.47 & 0.00 & 0.00 & 0.00 & 0.00 & 0.00 \\
\hline 2 & 3.67 & 63.09 & 25.63 & 1.62 & 3.19 & 2.06 & 0.13 & 4.27 \\
\hline 3 & 3.70 & 61.94 & 25.95 & 1.68 & 3.34 & 2.57 & 0.23 & 4.28 \\
\hline 4 & 3.74 & 60.91 & 25.54 & 1.93 & 4.03 & 2.74 & 0.23 & 4.61 \\
\hline 5 & 3.77 & 59.71 & 25.12 & 1.93 & 4.05 & 4.38 & 0.23 & 4.58 \\
\hline 6 & 3.79 & 59.03 & 24.84 & 1.91 & 4.01 & 4.91 & 0.77 & 4.53 \\
\hline 7 & 3.80 & 58.90 & 24.75 & 1.91 & 4.06 & 5.05 & 0.81 & 4.52 \\
\hline 8 & 3.81 & 58.61 & 24.70 & 1.92 & 4.32 & 5.09 & 0.86 & 4.50 \\
\hline 9 & 3.82 & 58.43 & 24.58 & 1.92 & 4.43 & 5.18 & 0.93 & 4.54 \\
\hline 10 & 3.83 & 58.32 & 24.53 & 1.93 & 4.56 & 5.16 & 0.97 & 4.53 \\
\hline
\end{tabular}

Cholesky Ordering: RFLOWS, $\mathrm{R}_{\mathrm{REIT}}, \mathrm{R}_{\mathrm{f}}$, YLDSP, $\mathrm{R}_{\mathrm{MKT}}-\mathrm{R}_{\mathrm{f}} \mathrm{SMB}$, HML. See Table 4 for variable definitions. 
Table 6

Weekly Vector Autoregressive Model Estimates: 1992:01 - 2003:08

\begin{tabular}{|c|c|c|c|c|c|c|}
\hline \multirow[t]{2}{*}{ Variables } & \multicolumn{2}{|c|}{ Bivariate Model } & \multicolumn{2}{|c|}{ Four-Factor Model } & \multicolumn{2}{|c|}{ Seven-Factor Model } \\
\hline & RFLOWS & $\mathrm{R}_{\text {REIT }}$ & RFLOWS & $\mathrm{R}_{\text {REIT }}$ & RFLOWS & $\mathrm{R}_{\text {REIT }}$ \\
\hline Constant & $\begin{array}{c}0.006 * * * \\
(2.510)\end{array}$ & $\begin{array}{c}0.233 * * * \\
(2.881)\end{array}$ & $\begin{array}{c}0.025^{* * * *} \\
(2.819)\end{array}$ & $\begin{array}{c}0.219 \\
(0.698)\end{array}$ & $\begin{array}{c}0.027 * * * \\
(3.033)\end{array}$ & $\begin{array}{c}0.255 \\
(0.802)\end{array}$ \\
\hline RFLOWS (-1) & $\begin{array}{c}0.299 * * * \\
(6.917)\end{array}$ & $\begin{array}{c}0.763 \\
(0.492)\end{array}$ & $\begin{array}{c}0.287 * * * \\
(6.580)\end{array}$ & $\begin{array}{c}1.065 \\
(0.693)\end{array}$ & $\begin{array}{c}0.279 * * * \\
(6.311)\end{array}$ & $\begin{array}{c}1.317 \\
(0.846)\end{array}$ \\
\hline RFLOWS (-2) & $\begin{array}{c}0.157 * * * \\
(3.537)\end{array}$ & $\begin{array}{c}2.294 \\
(1.440)\end{array}$ & $\begin{array}{c}0.146^{* * * *} \\
(3.258)\end{array}$ & $\begin{array}{c}2.339 \\
(1.482)\end{array}$ & $\begin{array}{c}0.136 * * * \\
(2.984)\end{array}$ & $\begin{array}{c}2.240 \\
(1.402)\end{array}$ \\
\hline RFLOWS (-3) & $\begin{array}{c}0.145^{* * * *} \\
(3.266)\end{array}$ & $\begin{array}{c}-0.756 \\
(-0.476)\end{array}$ & $\begin{array}{c}0.129 * * * \\
(2.889)\end{array}$ & $\begin{array}{c}-0.562 \\
(-0.357)\end{array}$ & $\begin{array}{c}0.125 * * * \\
(2.785)\end{array}$ & $\begin{array}{c}-0.717 \\
(-0.453)\end{array}$ \\
\hline RFLOWS (-4) & $\begin{array}{l}0.080 * \\
(1.940)\end{array}$ & $\begin{array}{c}-0.777 \\
(-0.527)\end{array}$ & $\begin{array}{c}0.065 \\
(1.573)\end{array}$ & $\begin{array}{c}-0.640 \\
(-0.438)\end{array}$ & $\begin{array}{l}0.071 * \\
(1.690)\end{array}$ & $\begin{array}{c}-0.887 \\
(-0.602)\end{array}$ \\
\hline $\mathrm{R}_{\text {REIT }}(-1)$ & $\begin{array}{c}0.007 * * * \\
(6.041)\end{array}$ & $\begin{array}{c}0.003 \\
(0.071)\end{array}$ & $\begin{array}{c}0.007 * * * \\
(5.535)\end{array}$ & $\begin{array}{c}-0.043 \\
(-0.993)\end{array}$ & $\begin{array}{c}0.008 * * * \\
(5.138)\end{array}$ & $\begin{array}{c}-0.031 \\
(-0.551)\end{array}$ \\
\hline $\mathrm{R}_{\text {REIT }}(-2)$ & $\begin{array}{c}-0.001 \\
(-0.216)\end{array}$ & $\begin{array}{c}-0.090 * * \\
(-2.013)\end{array}$ & $\begin{array}{c}-0.001 \\
(-0.397)\end{array}$ & $\begin{array}{c}-0.130 * * * \\
(-2.929)\end{array}$ & $\begin{array}{c}0.002 \\
(1.125)\end{array}$ & $\begin{array}{c}-0.213 * * * \\
(-3.657)\end{array}$ \\
\hline $\mathrm{R}_{\mathrm{f}}(-1)$ & & & & $\begin{array}{c}-1.544 * * \\
(-1.964)\end{array}$ & & $\begin{array}{c}-1.669 * * \\
(-2.083)\end{array}$ \\
\hline $\mathrm{R}_{\mathrm{MKT}}-\mathrm{R}_{\mathrm{f}}(-2)$ & & & & & & $\begin{array}{c}0.135 * * * \\
(2.473)\end{array}$ \\
\hline HML(-2) & & & & & & $\begin{array}{l}0.121 * \\
(1.642)\end{array}$ \\
\hline Adj. R-squared & 0.38 & 0.01 & 0.38 & 0.04 & 0.38 & 0.05 \\
\hline
\end{tabular}

(t-statistics in parentheses: $* * *, * * * ; 1 \%, 5 \%$, and $10 \%$ significance levels respectively)

We estimate the following unrestricted VAR model:

$$
Y_{t}=\mu+\Phi_{1} Y_{t-1}+\Phi_{2} Y_{t-2}+\ldots+\Phi_{k} Y_{t-p}+e_{t}
$$

where $\mathrm{Y}_{\mathrm{t}}$ is a vector of variables, $\mu$ is a $p \times 1$ vector of intercepts, $\Phi_{1}, \Phi_{2}, \ldots, \Phi_{\mathrm{k}}$ are $p \times p$ matrices of parameters with all eigenvalues of $\Phi$ having moduli less than one so that the VAR is stationary, and $e_{t}$ is a vector of uncorrelated structural shocks $[\sim N I D(0, \Omega)]$. We obtain maximum likelihood parameter estimates using iterated least squares. The lag-length of the VAR is chosen by looking at the AIC and the likelihood ratio for various choices of $p$. The bivariate model consists of weekly dedicated REIT mutual fund flows relative to the total REIT stock market capitalization lagged three months (RFLOWS) and REIT returns $\left(R_{R E I T}\right)$. The four-factor model also includes yields on one-week Treasury securities $\left(R_{f}\right)$ and the NAREIT dividend yield spread (YLDSP). The seven-factor model adds the Fama-French factors $\left(R_{M K T}-R_{f}, S M B\right.$, and $H M L)$. 
Table 7

Monthly Vector Autoregressive Model Estimates: NAV Specifications

\begin{tabular}{|c|c|c|c|c|c|c|}
\hline \multirow[t]{2}{*}{ Variables } & \multicolumn{2}{|c|}{ Bivariate Model } & \multicolumn{2}{|c|}{ Four-Factor Model } & \multicolumn{2}{|c|}{ Seven-Factor Model } \\
\hline & RFLOWS & PNAV & RFLOWS & PNAV & RFLOWS & PNAV \\
\hline Constant & $\begin{array}{c}0.50 * * \\
(2.39)\end{array}$ & $\begin{array}{c}0.41 \\
(1.05)\end{array}$ & $\begin{array}{c}0.76 \\
(0.92)\end{array}$ & $\begin{array}{c}0.15 \\
(0.10)\end{array}$ & $\begin{array}{c}0.88 \\
(0.98)\end{array}$ & $\begin{array}{c}0.76 \\
(0.46)\end{array}$ \\
\hline RFLOWS (-1) & $\begin{array}{c}0.30 \text { *** } \\
(2.79)\end{array}$ & $\begin{array}{c}0.00 \\
(0.21)\end{array}$ & $\begin{array}{c}0.30 * * * \\
(2.74)\end{array}$ & $\begin{array}{c}0.12 \\
(0.61)\end{array}$ & $\begin{array}{c}0.34 * * * \\
(2.89)\end{array}$ & $\begin{array}{c}0.23 \\
(1.05)\end{array}$ \\
\hline RFLOWS (-2) & $\begin{array}{c}0.13 \\
(1.22)\end{array}$ & $\begin{array}{c}0.10 \\
(0.51)\end{array}$ & $\begin{array}{c}0.14 \\
(1.27)\end{array}$ & $\begin{array}{c}0.11 \\
(0.55)\end{array}$ & $\begin{array}{c}0.14 \\
(1.24)\end{array}$ & $\begin{array}{c}0.15 \\
(0.69)\end{array}$ \\
\hline PNAV (-1) & $\begin{array}{c}0.16 * * * \\
(2.87)\end{array}$ & $\begin{array}{c}0.90 * * * \\
(8.53)\end{array}$ & $\begin{array}{c}0.20 * * * \\
(3.17)\end{array}$ & $\begin{array}{c}0.93 * * * \\
(7.86)\end{array}$ & $\begin{array}{c}0.19 * * * \\
(2.66)\end{array}$ & $\begin{array}{c}0.85 * * * \\
(6.59)\end{array}$ \\
\hline PNAV(-2) & $\begin{array}{c}-0.02 \\
(-0.28)\end{array}$ & $\begin{array}{c}-0.01 \\
(-0.08)\end{array}$ & $\begin{array}{c}-0.00 \\
(-0.04)\end{array}$ & $\begin{array}{c}-0.01 \\
(-0.05)\end{array}$ & $\begin{array}{c}-0.02 \\
(-0.19)\end{array}$ & $\begin{array}{c}-0.03 \\
(-0.18)\end{array}$ \\
\hline $\mathrm{R}_{\mathrm{MKT}}-\mathrm{R}_{\mathrm{f}}(-1)$ & & & & & & $\begin{array}{c}0.24 * * * \\
(2.52)\end{array}$ \\
\hline $\operatorname{HML}(-1)$ & & & & & & $\begin{array}{l}0.21^{*} \\
(1.92)\end{array}$ \\
\hline Adj. R-squared & 0.37 & 0.87 & 0.39 & 0.87 & 0.36 & 0.87 \\
\hline
\end{tabular}

(t-statistics in parentheses: $* * * * * * * ; 1 \%, 5 \%$, and $10 \%$ significance levels respectively)

We estimate the following unrestricted VAR model:

$$
Y_{t}=\mu+\Phi_{1} Y_{t-1}+\Phi_{2} Y_{t-2}+\ldots+\Phi_{k} Y_{t-p}+e_{t},
$$

where $Y_{\mathrm{t}}$ is a vector of variables, $\mu$ is a $p \times 1$ vector of intercepts, $\Phi_{1}, \Phi_{2}, \ldots, \Phi_{\mathrm{k}}$ are $p \times p$ matrices of parameters with all eigenvalues of $\Phi$ having moduli less than one so that the VAR is stationary, and $\mathrm{e}_{\mathrm{t}}$ is a vector of uncorrelated structural shocks $[\sim N I D(0, \Omega)]$. We obtain maximum likelihood parameter estimates using iterated least squares. The lag-length of the VAR is chosen by looking at the AIC and the likelihood ratio for various choices of $p$. The bivariate model consists of monthly dedicated REIT mutual fund flows relative to total REIT stock market capitalization lagged three months (RFLOWS) and Green Street Net Asset Value Premiums (PNAV). The four-factor model also includes returns on onemonth Treasury securities $\left(R_{f}\right)$ and the NAREIT dividend yield spread (YLDSP). The seven-factor model adds the Fama-French factors $\left(R_{M K T}-R_{f}, S M B\right.$, and $\left.H M L\right)$. 